\title{
CORRESPONDENCE.
}

FOSSILS FROM VITI LEVU.

SIr,---In a paper by Dr. Matley and myself on Viti Levu, in the Geological Magazine for 1927 (Vol. LXIV, pp. 65-75), I described a fossil as Nodularia vitiensis. I learn from Professor H. S. Ladd of the University of Virginia that he has obtained better material from the same beds, and the photographs and descriptions which he has very kindly sent me show clearly that the remains are those of marine, not freshwater, shells. I had considered the possibility of my specimens belonging to the Mactracea, but on the balance of evidence available decided in favour of the Naiadacea. Professor Ladd has now found a definitely mactroid hinge-line in a form which, if not identical with vitiensis, is very close to it. The palaeogeographical conclusions which I ventured to found on the occurrence of a Nodularia in Viti Levu consequently fall.

A. Morley Davies.

\section{RAISED BEACHES IN LOCH TORRIDON AND LOCH ERRIBOL.}

Sir,-In a recent number of the Geological Magazine Mr. D. M. Reid says that he finds himself unable to agree with me that raised beaches occur in these two lochs, as stated on p. 321 of my contribution to the Handbuch der Regionalen Geologie. But for the compression necessary in a work of that character it would have appeared that my statement was a quotation from a paper by Mr. L. W. Hinxman (Trans. Geol. Soc. of Edinb., vol. vi, pt. iv, p. 249) wherein the author says "at the head of Loch Torridon the 25 and 50 feet raised beaches form a plateau of considerable extent, the latter extending for more than a mile up Glen Torridon". On p. 251 he says " at the head of Loch Erribol in North Sutherland, as has been pointed out by Sir Archibald Geikie ${ }^{1}$ and as my friends and colleagues, Messrs. Peach and Horne, have shown by detailed mapping, similar phenomena occur, though in that locality satisfactory sections, such as those described above, are wanting."

I do not profess to adjudicate between Mr. Reid and the geologists who mapped the alleged beaches, but I venture to think that Mr. Reid might re-examine the evidence : it would be passing strange if Peach and Horne were wrong in the interpretation of their mapping.

Frinton, Essex.

Percy F. Kendali.

\section{A Correction.}

Owing to absence abroad Dr. J. Parkinson was unable to see a proof of his letter in the December number on the Deinosaur beds of Tendaguru; the accidental omission of a word spoilt the meaning of one sentence. On p. 560, lines 20-1 should read: " brackish water conditions alternated with local marine episodes."

1 Scenery of Scotland, 2nd ed.. 1887, p. 272. 